\title{
Use of Phosphonate to Manage Foliar Potato Late Blight in Developing Countries
}

Peter Kromann, International Potato Center (CIP), P.O. Box 17-19-129, Quito, Ecuador; Willmer G. Pérez, CIP, P.O. Box 1558, Lima 12, Peru; Arturo Taipe, CIP, P.O. Box 17-19-129, Quito, Ecuador; Elmar Schulte-Geldermann, CIP, P.O. Box 25171, Nairobi, Kenya; Buddhi Prakash Sharma, National Potato Research Programme, Khumaltar, Lalitpur, Nepal; Jorge L. Andrade-Piedra, CIP, P.O. Box 17-19-129, Quito, Ecuador; and Gregory A. Forbes, CIP, 12 Zhongguancun South St., Beijing, China, 100081

\begin{abstract}
Kromann, P., Pérez, W. G., Taipe, A., Schulte-Geldermann, E., Sharma, B. P., Andrade-Piedra, J. L., and Forbes, G. A. 2012. Use of phosphonate to manage foliar potato late blight in developing countries. Plant Dis. 96:1008-1015.

Twenty phosphonate products found in the agrochemical market in Ecuador and Peru were evaluated in bioassays for the control of foliar potato late blight, caused by Phytophthora infestans. Eight phosphonate products were evaluated in 16 field experiments done in Peru, Ecuador, Kenya, and Nepal. A meta-analysis across locations involving 71 combinations of potato genotype by site and year demonstrated a significant relationship between phosphonate application rate and efficacy for controlling late blight on potato foliage. The meta-analysis revealed that phosphonate rates of approximately $2.5 \mathrm{~g}$ a.i./liter provided efficacy similar to that of the conventional contact fungicides

mancozeb and chlorothalonil used at similar rates. At rates higher than $2.5 \mathrm{~g}$ a.i./liter, the efficacy of phosphonate was superior to the contact fungicides. Overall, late blight control by phosphonate appeared relatively stable in field experiments across locations. An analysis of field experiments and 64 combinations of potato genotype by site and year showed no correlation between the susceptibility level of potato genotypes and efficacy of phosphonates. The cost of both phosphonate compounds and contact fungicides varied greatly among the countries of the field study; however, in Kenya, control with phosphonate was clearly less expensive than with mancozeb.
\end{abstract}

Potato is an important food and cash crop for many poor people and is often considered an important mechanism for poverty alleviation and food security in developing countries (34). Based on the number of hectares harvested and metric tons produced, potato is one of the fastest growing staple food crops in the subtropics and tropics (12).

One factor limiting the potential of increased potato production in developing countries is late blight caused by the oomycete pathogen, Phytophthora infestans. Late blight occurs on potato worldwide and is considered the world's most costly disease on food crops (17). In most parts of the developing world, the most widely grown potato genotypes are susceptible to late blight, and fungicides are a necessity for crop production. In some areas of Indonesia, farmers are known to use up to 30 fungicide sprays to harvest a single crop, while 15 or more sprays have been recorded in the Andes (33).

The fungicides most commonly used for control of late blight in the developing world are the low-cost dithiocarbamate-type contact fungicides, particularly mancozeb. In a recent visit to the Lake Kivu area in Rwanda by one of the authors, mancozeb was the most widely used late blight control compound and was the only contact fungicide available for both potato and tomato. Mancozeb can cause dermatitis and eye problems (7) and is considered hazardous among occupational health researchers (39). Mancozeb was reevaluated in the European Union (EU) and has been allowed for use under European conditions (4); the U.S. Environmental Protection Agency (US-EPA) has also determined that mancozeb products are eligible for reregistration in the United States. However, there remains considerable concern over the health hazard this dithiocarbamate represents (11). In developing countries, exposure of farm workers and their families to pesticides is much greater than in the EU or the United States. In developing countries,

Corresponding author: G. A. Forbes, E-mail: g.forbes@cgiar.org

Accepted for publication 9 February 2012.

http://dx.doi.org/10.1094/PDIS-12-11-1029-RE

(C) 2012 The American Phytopathological Society protective clothing is not used by the vast majority of farmers, pesticide contaminated clothing is brought into the home, and pesticides are often stored in or near homes $(8,29,31)$.

To provide farmers with safer alternatives to late blight management, the International Potato Center (CIP) and partners are investigating the efficacy of phosphonate fungicides for control of potato late blight. Phosphonate is an alternative that appears to be appropriate for developing countries, primarily because it represents a low risk to human health and environment (16). Phosphonate fungicides are classified as biopesticides by the US-EPA, and the environmental impact quotient (EIQ), a composite hazard indicator developed at Cornell University, rates phosphonates with the value 8.7 , while mancozeb is rated with 25.7 and chlorothalonil with the value $37.4(20,21)$.

Phosphonates are generally applied as salts of phosphorous acid, also called phosphites. The aluminum salt of phosphorous acid, also known as fosetyl-Al, has been used as a fungicide against Oomycetes for decades $(6,32,40)$ in Europe and North America, while other salts, particularly potassium-phosphite, have been widely used in Australia and Asia for control of Phytophthora diseases in plantation crops. Nonetheless, the full potential of salts of phosphorous acid for controlling late blight on potato foliage is still not well understood.

The phosphonate salts are metabolized to phosphorous acid inside plants (13). The phosphonate anion $\left(\mathrm{HPO}_{3}{ }^{2-}\right)$, also named phosphite, is the hydrolysis product of phosphorous acid, also called phosphonic acid $\left(\mathrm{H}_{3} \mathrm{PO}_{3}\right)$. Phosphorous acid is exceptionally mobile in the phloem of plants, moving both up and down stems (6). Phosphonate has been shown to inhibit oxidative phosphorylation in the metabolism of Oomycetes $(14,16,30,35)$ and block essential pathogen enzymes, thereby limiting mycelial growth directly $(16,35,36)$. Additionally, research has shown that phosphonate has an indirect effect on pathogen infection by stimulating plants' natural defense mechanisms $(1,10,16,18,32,35)$. Recent studies have shown the activation of induced resistance and an increase in pathogenesis-related proteins in potato after application of phosphonates $(3,24)$.

Control of potato late blight with foliar application of fosetyl-Al, ammonium, calcium, potassium, and sodium phosphonates or $\mathrm{pH}$ 
neutralized phosphorous acid has been reported from several studies $(9,19,25,27,38)$. A previous paper reported successful control of tuber blight and foliar late blight with potassium phosphonates, and some control with fosetyl-Al (27). A study on potted potato plants in Argentina reported successful control of late blight in foliage and tubers with potassium and calcium phosphites (25). Likewise, authors from Northern Ireland reported successful control in tubers following foliar application of phosphonate formulations, but insufficient control in foliage (9). Ambiguous and inconsistent field results have led several research groups to propose that the activity of phosphonates may be influenced by factors such as host plant genotype, environment, and factors related to the formulation applied and timing of application $(9,25,27)$.

Currently, there are numerous chemical companies that market metal-phosphonate salts as either fertilizers, activators of natural resistance, or systemic fungicides. In many countries, agrochemical companies avoid the cost associated with registering a fungicide by labeling their phosphonate formulations as fertilizer. This has resulted in the marketing of countless phosphonate-containing plant improvement products for which the fungicidal effect on $P$. infestans in potato tubers or foliage is unclear.

In this study, a series of experiments was implemented in highland tropical areas to evaluate the efficacy of phosphonate products commonly found in local agrochemical markets for the control of late blight on potato foliage. The efficacy of phosphonates and their potential to induce resistance against late blight could be linked to genotypic interactions and the susceptibility level of potato genotypes. Thus, potato genotype effects were evaluated as well as different application rates and product formulations. We report on results of individual experiments with detached leaflets and potted potato plants, and also a meta-analysis of field trials from Peru, Ecuador, Kenya, and Nepal. The primary hypothesis in our study was that phosphonate compounds can control late blight on potato foliage as well as conventional contact fungicides (principally mancozeb) on a per unit basis. Preliminary economic analyses were also done by assessing retail prices and comparing prices for spray mixes of phosphonate products with equivalent spray mixes of conventional fungicides.

\section{Materials and Methods}

Preliminary bioassays. Two bioassays were conducted at CIP's headquarters in Lima, Peru in 2006 and a third in Ecuador at CIP's experimental station near Quito in 2007. The bioassays were designed to investigate the efficacy of phosphonate formulations found on the Peruvian and Ecuadorian agrochemical markets for control of $P$. infestans in potato foliage. Both detached leaflets and potted potato plants were used to select the most promising products for further investigation in field experiments.
In Peru, seven phosphonate products were compared to mancozeb and a water control (Table 1). A detached leaflet assay under controlled conditions and a whole plant assay in a screenhouse were each repeated three times. For both types of assays, plants of potato cultivar Yungay, which has a susceptibility scale value of 7 (1 highly resistant, 9 susceptible [41]), were grown in 20-cm-diameter pots in soil substrate and maintained in a screenhouse with 12-h natural daylight and temperatures ranging from 15 to $22^{\circ} \mathrm{C}$. The pots were placed in a completely randomized block design with five replications. All products were applied on the same date (42, 51, and 56 days after planting in the three repetitions, respectively) to five plants per treatment with the respective recommended label rates of each product (Table 1). Formulations and the water control were applied to plants by spraying till run-off with a lever-operated knapsack sprayer with a maximum working pressure of approximately 44 psi. A $P$. infestans sporangia suspension adjusted to $5 \times$ $10^{3}$ sporangia/ml was prepared from an isolate from the CIP-Lima culture collection (PCO76; EC-1 lineage). Inoculum was prepared as described previously by Andrade-Piedra et al. (2).

For the detached leaflet assay, one leaflet per plant was detached arbitrarily from the fourth to sixth fully expanded leaves of each plant $24 \mathrm{~h}$ after product application. Leaflets were inoculated by spraying the sporangial suspension onto the adaxial side of leaflets with a hand-held atomizer until run-off. Inoculated leaflets were placed adaxial side up in the cover of inverted 9-cm-diameter petri plates with $1.5 \%$ water agar in the base, one leaflet per plate, and five leaflets per treatment. Petri plates were sealed with Parafilm and incubated at $18^{\circ} \mathrm{C}$ and 12-h day photoperiod for 6 days. Infection efficiency (IE) was calculated as the percentage of inoculated leaflets with necrotic spots after the 6 days of incubation, and infected leaf area (ILA) was visually estimated as the area (\%) on infected leaflets with necrotic spots.

For the whole plant assay, the plants were inoculated by spraying the sporangial suspension $\left(5 \times 10^{3}\right.$ sporangia/ml $)$ onto all of the foliage of each plant until run-off with a hand-held atomizer. After inoculation, screenhouse conditions conducive to late blight were maintained by misting with overhead sprinklers for 15 min every 2 $\mathrm{h}$ during the day. In addition, a plastic cover was placed over the plants during the nights to maintain high humidity. The temperature in the screenhouse ranged from 15 to $20^{\circ} \mathrm{C}$. After 6 days, IE and ILA were visually estimated.

In Ecuador, 13 phosphonate products were also compared to mancozeb and a water control in a detached leaflet assay (Table 2). Potato cultivar Fripapa, which has a susceptibility scale value of 6 (41), and the CIP-Quito breeding clone C11 (estimated scale value of 2) and the CIP breeding clone LBR-47 (CIP 387334.5; estimated scale value of 8 ), were grown in a screenhouse with natural light and temperatures ranging from 8 to $30^{\circ} \mathrm{C}$. Five plants were

Table 1. Infection efficiency and infected leaf area in a detached leaflet bioassay and a whole plant bioassay with the potato cultivar Yungay inoculated with Phytophtora infestans, lineage EC-1 in Peru, 2006 (mean \pm standard error)

\begin{tabular}{|c|c|c|c|c|c|c|c|}
\hline \multirow[b]{2}{*}{$\begin{array}{l}\text { Treatment } \\
\text { Brand name }\end{array}$} & \multirow[b]{2}{*}{ Phosphite salt } & \multirow[b]{2}{*}{$\begin{array}{l}\text { Conc. a.i. }{ }^{a} \\
(\%, w t / v o l)\end{array}$} & \multirow[b]{2}{*}{$\begin{array}{c}\text { Rate } \\
\text { (g a.i./liter) }\end{array}$} & \multicolumn{2}{|c|}{ Detached leaflets } & \multicolumn{2}{|c|}{ Whole plants } \\
\hline & & & & $\begin{array}{c}\text { Infection } \\
\text { efficiency }^{\mathbf{b}}(\%)\end{array}$ & $\begin{array}{l}\text { Infected leaf } \\
\text { area }(\%)\end{array}$ & $\begin{array}{c}\text { Infection } \\
\text { efficiencyc }^{c}(\%)\end{array}$ & $\begin{array}{c}\text { Infected leaf } \\
\text { area }(\%)\end{array}$ \\
\hline CunebForte & $\mathrm{K}$ & 84 & 2.10 & $0 \pm 0$ & $0 \pm 0$ & $17 \pm 17$ & $5 \pm 5$ \\
\hline Nutralex-K & $\mathrm{K}$ & 84 & 4.20 & $0 \pm 0$ & $0 \pm 0$ & $0 \pm 0$ & $0 \pm 0$ \\
\hline Greenzit Max-Ald & $\mathrm{Al}$ & - & - & $11 \pm 11$ & $13 \pm 3$ & $50 \pm 50$ & $10 \pm 10$ \\
\hline Fitopron & $\mathrm{K}$ & 70 & 1.75 & $11 \pm 11$ & $25 \pm 5$ & $17 \pm 17$ & $25 \pm 25$ \\
\hline Trafos $\mathrm{Cu}^{\mathrm{e}}$ & $\mathrm{K}$ & 72 & 1.75 & $36 \pm 22$ & $19 \pm 4$ & $50 \pm 50$ & $30 \pm 30$ \\
\hline Phuxan & $\mathrm{K}$ & 70 & 1.75 & $11 \pm 11$ & $50 \pm 30$ & $0 \pm 0$ & $0 \pm 0$ \\
\hline Fitofosfito & $\mathrm{K}$ & 70 & 1.75 & $11 \pm 11$ & $55 \pm 35$ & $25 \pm 25$ & $5 \pm 5$ \\
\hline Dithane M-45 & Mancozeb & $80(w t / w t)$ & 1.60 & $8 \pm 8$ & $20 \pm 20$ & $50 \pm 50$ & $10 \pm 10$ \\
\hline Control & Dis. water ${ }^{\mathrm{f}}$ & & & $100 \pm 0$ & $84 \pm 3$ & $50 \pm 50$ & $60 \pm 60$ \\
\hline
\end{tabular}

a Concentration of active ingredient as indicated on label.

b Infection efficiency $=$ number of leaflets infected relative to number of leaflets inoculated.

c Infection efficiency $=$ number of plants infected relative to number of plants inoculated.

$\mathrm{d}$ The label on Greenzit Max-Al described the product as aluminum phosphite that contains elements of $\mathrm{Cu}$, Mn, N. The concentration of phosphite was not indicated.

e Trafos $\mathrm{Cu}$ contains elements of $\mathrm{Cu}$.

f Distilled sterile water. 
used for each product-genotype combination. The pots were placed in a completely randomized block design with five replications of 45 product-genotype combinations. Phosphonate products were applied 45 days after planting. Rates varied among products, and between 3.0 and $4.4 \mathrm{~g}$ a.i./liter was prepared according to the manufacturers' specifications of each product (Table 2). Mancozeb was applied at a rate of $2.4 \mathrm{~g}$ a.i./liter. Three arbitrarily selected leaflets from different non-terminal leaves were detached from each plant 8 days after product application. The leaflets were placed adaxial side up in the cover of an inverted 9-cm-diameter petri plate with water agar in the base. From a $P$. infestans isolate from the CIP-Quito collection (no. 3793; EC-1 lineage), sporangia were produced on leaflets of cultivar Gabriela and a sporangia suspension was adjusted to $20 \times 10^{3}$ sporangia/ml using the method described previously by Andrade-Piedra et al. (2). Following zoospore release, each leaflet was inoculated with a $50-\mu 1$ drop of the suspension by placing it on the midrib of the adaxial side of each leaflet. Petri plates containing the inoculated leaflets were placed in a growth chamber adjusted to a 14-h day photoperiod and $18^{\circ} \mathrm{C}$. After 4 days of incubation, IE was evaluated visually. After 6 days of incubation, lesion size (LS, $\mathrm{mm}^{2}$ ) was measured with digital photographs and ImageJ software (National Institutes of Health, Bethesda, MD, USA).

Field experiments. A total of 16 field experiments were done in Ecuador, Peru, Kenya, and Nepal at 11 sites, and involved 29 potato genotypes. Ecuador, Peru, and Kenya are countries where CIP has experiment stations and good facilities for doing late blight research in the field. Nepal is one of CIP's target countries and a principal collaborator concerning research on late blight in Asia. Three experiments were done in Ecuador between 2008 and 2010 involving six potato genotypes. Two of these experiments were done on CIP's experiment station near Quito and one at the Provincial government's experiment station "Granja Agroecologica" in Pillaro, Tungurahua. Eight experiments were carried out in Peru between 2007 and 2009, and involved nine genotypes: two were carried out in farmers' fields in Cajamarca in the north; and six were carried out in the central part of Peru, four in farmers' fields in Junin and Pasco and two at CIP's experiment station in Huancayo. Four experiments were carried out in Kenya between 2009 and 2010, and involved 13 genotypes: three experiments were done at the University of Nairobi and one at Koibatek in the Rift Valley Province. One experiment was carried out in Nepal involving the cultivar Kufri Jyoti at the National Potato Research Programme's experiment station in Khumaltar.

Late blight control treatments included one or more phosphonate formulations in each experiment (Table 3). The phosphonate treat- ments were also compared with at least one conventional fungicide treatment and a control treatment without fungicide application (Table 3). In all experiments in Peru, the phosphonate applications were compared to (i) applications of phosphonate applied in alternation with a contact fungicide (Table 3); (ii) a treatment without fungicide; and (iii) fungicide treatments based on local farmer choices specific to each location, which generally involved numerous sprays with both conventional systemic and contact fungicides exclusively (information on (iii) is not shown in Table 3). In all experiments, fungicides were applied with lever-operated knapsack sprayers with maximum working pressures of approximately 44 psi. Fungicides were applied to foliage until run-off, using estimated volumes of 300 to 1,200 liter/ha of water per spray application depending on the phenological growth stage of the potato crop. Different application rates for the same fungicide product were frequently used in the different locations (Table 3 ).

Experimental design and agronomic practices. All field experiments were set up with a one- or two-way factorial design with the one factor being late blight fungicide treatment, and the other potato genotype if the experiment included more than one genotype. Experimental units were replicated three or four times. The experiment carried out in Ecuador in 2008 used a strip-plot design, and the experiments in Ecuador in 2009 and 2010 used split-plot designs; and the experiments in Peru and Kenya used strip-plot designs. The experiment in Nepal used a randomized complete block design. Planting was done prior to the principal rainy period at each location to ensure late blight disease pressure from naturally occurring inoculum. Local planting practices were used at each location with experimental units consisting of equal-size plots ( 7 to $67 \mathrm{~m}^{2}$ ) containing from 30 to 200 potato plants per plot. To help differentiate experimental units and to reduce inter-plot inoculum interference, a 1- to 2-m strip of land, noncultivated or planted with oats (Avena sativa), surrounded each plot. Insect and weed control using insecticides and herbicides, as well as fertilization, were done according to local integrated crop management recommendations. The experimental fungicide treatments generally started at $80 \%$ emergence in all experiments, and approximately 30 days after planting. However, experiments in Peru included one or two early sprays with mancozeb applied at weekly intervals, and applied to all treatments including control treatments to protect emerging plants from early and unevenly distributed inoculum sources. Likewise, experiments in Ecuador included one early protective spray applied about 25 days after planting with dimethomorph or cymoxanil to all treatments, including the control treatment. Approximately 10 days after the last of these protective sprays was applied, the experimental treatments were initiated in

Table 2. Infection efficiency and lesion size in three potato genotypes using detached leaves inoculated with Phytophtora infestans, lineage EC-1 in Ecuador, 2007 (mean \pm standard error)

\begin{tabular}{|c|c|c|c|c|c|c|c|c|c|}
\hline \multirow{3}{*}{$\begin{array}{l}\text { Treatment } \\
\text { Brand name }\end{array}$} & \multirow{3}{*}{$\begin{array}{c}\text { Phosphite } \\
\text { salt }\end{array}$} & \multirow{3}{*}{$\begin{array}{l}\text { Conc. a.i. }{ }^{b} \\
(\%, \text { wt/vol })\end{array}$} & \multirow{3}{*}{$\begin{array}{c}\text { Rate (g } \\
\text { a.i./liter) }\end{array}$} & \multicolumn{3}{|c|}{ Infection efficiency $^{\mathrm{a}}(\%)$} & \multicolumn{3}{|c|}{ Lesion size $\left(\mathrm{mm}^{2}\right)$} \\
\hline & & & & \multicolumn{3}{|c|}{ Potato genotype } & \multicolumn{3}{|c|}{ Potato genotype } \\
\hline & & & & C11 & Fripapa & LBR-47 & C11 & Fripapa & LBR-47 \\
\hline Fosphitall 302 & $\mathrm{~K}$ & 70 & 4.2 & $0 \pm 0$ & $0 \pm 0$ & $0 \pm 0$ & $0 \pm 0$ & $0 \pm 0$ & $0 \pm 0$ \\
\hline Glass-K & $\mathrm{K}$ & 58 & 3.5 & $0 \pm 0$ & $0 \pm 0$ & $0 \pm 0$ & $0 \pm 0$ & $0 \pm 0$ & $0 \pm 0$ \\
\hline Glass-Cal & $\mathrm{Ca}$ & 24 & 3.6 & $0 \pm 0$ & $0 \pm 0$ & $0 \pm 0$ & $0 \pm 0$ & $0 \pm 0$ & $0 \pm 0$ \\
\hline Glass-Ca+Mg & $\mathrm{Ca}+\mathrm{Mg}$ & 34 & 3.4 & $0 \pm 0$ & $0 \pm 0$ & $0 \pm 0$ & $0 \pm 0$ & $0 \pm 0$ & $0 \pm 0$ \\
\hline Agrifos $400 \mathrm{LS}$ & $\mathrm{K}+\mathrm{K}_{2}$ & 46 & 3.2 & $0 \pm 0$ & $0 \pm 0$ & $27 \pm 13$ & $0 \pm 0$ & $0 \pm 0$ & $12 \pm 6$ \\
\hline Glass-Mg+B & $\mathrm{Mg}+\mathrm{B}$ & 63 & 4.4 & $0 \pm 0$ & $0 \pm 0$ & $27 \pm 13$ & $0 \pm 0$ & $0 \pm 0$ & $21 \pm 10$ \\
\hline Cooper feed & $\mathrm{Cu}$ & 65 & 3.2 & $0 \pm 0$ & $0 \pm 0$ & $40 \pm 19$ & $0 \pm 0$ & $0 \pm 0$ & $91 \pm 62$ \\
\hline Quinopron & $\mathrm{K}$ & 70 & 4.2 & $0 \pm 0$ & $0 \pm 0$ & $13 \pm 8$ & $0 \pm 0$ & $0 \pm 0$ & $92 \pm 81$ \\
\hline Codafol & K & 50 & 3.0 & $0 \pm 0$ & $0 \pm 0$ & $60 \pm 25$ & $0 \pm 0$ & $0 \pm 0$ & $112 \pm 65$ \\
\hline Glass-Mg & $\mathrm{K}+\mathrm{Mg}$ & 69 & 4.1 & $0 \pm 0$ & $0 \pm 0$ & $33 \pm 0$ & $0 \pm 0$ & $0 \pm 0$ & $143 \pm 72$ \\
\hline Kalex & K & 70 & 4.2 & $0 \pm 0$ & $0 \pm 0$ & $40 \pm 19$ & $0 \pm 0$ & $0 \pm 0$ & $171 \pm 87$ \\
\hline Dithane M-45 & Mancozeb & 80 (wt/wt) & 2.4 & $0 \pm 0$ & $0 \pm 0$ & $53 \pm 13$ & $0 \pm 0$ & $0 \pm 0$ & $253 \pm 98$ \\
\hline Saeta-Ca & $\mathrm{Ca}$ & $81(w t / w t)$ & 3.2 & $0 \pm 0$ & $0 \pm 0$ & $47 \pm 8$ & $0 \pm 0$ & $0 \pm 0$ & $318 \pm 113$ \\
\hline Fitopron & $\mathrm{K}$ & 70 & 4.2 & $60 \pm 13$ & $33 \pm 21$ & $87 \pm 13$ & $1,125 \pm 331$ & $68 \pm 36$ & $1,244 \pm 128$ \\
\hline Control & Dis. water & & & $100 \pm 0$ & $93 \pm 7$ & $100 \pm 0$ & $1,750 \pm 167$ & $1,542 \pm 116$ & $2,436 \pm 121$ \\
\hline
\end{tabular}

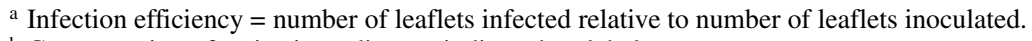

${ }^{b}$ Concentration of active ingredient as indicated on label. 
Peru and Ecuador. In all experiments, late blight epidemics were caused by natural infection, and potato plants were killed by late blight or left to senesce naturally before harvest.

Disease evaluation and data analysis. Visual estimates of late blight severity were recorded as the percentage of blighted foliage in each plot, and began approximately 1 month after planting and continued thereafter every 7 to 14 days depending on the development of each epidemic. Disease assessments continued until the non-fungicide-treated control plots planted to the most susceptible potato genotypes in an experiment had $100 \%$ infection. Disease assessment readings were used to calculate the area under the disease progress curve (AUDPC) using the midpoint rule (5). The AUDPC was also transformed into the relative AUDPC (RAUDPC) as described by Fry (15). Simple comparisons of the mean RAUDPC values for phosphonate, conventional fungicide, and control treatments were used to evaluate the efficacy of phosphonate products. For plotting purposes, the efficacy of phosphonate treatments compared to conventional fungicide treatments was further standardized using the following function expressing foliar late blight control efficacy $(E)$ :

$$
E=(\text { AUDPCcf }- \text { AUDPCp }) / \text { AUDPCc }
$$

where:

$A U D P C c f=$ AUDPC for conventional fungicide treatment,

$A U D P C p=$ AUDPC for phosphonate treatment,

$A U D P C c=$ AUDPC for control treatment without fungicide.
Thus, $E>0$ indicated phosphonate control greater than the conventional fungicide treatment, while $E<0$ indicated the opposite. $E$ was plotted against phosphonate rate and susceptibility levels of potato genotypes (estimated using the method of Yuen and Forbes [41]), to study the effect of phosphonate rate and host resistance, respectively, on efficacy of phosphonates. Statistical analyses were done using SAS 9.1 statistical software (SAS Institute Inc., Cary, NC).

Economic analysis. Retail prices of phosphonate products and conventional fungicides, which were evaluated in field experiments, were assessed by experienced local potato late blight researchers with extensive knowledge of the national fungicide markets in each of the four countries in 2011. Application prices were also estimated by calculating the price for 200 liters of spray mix with $2.5 \mathrm{~g}$ a.i./liter for each of the phosphonate products and conventional fungicides evaluated in the field experiments.

\section{Results}

Preliminary bioassays. In the bioassays in Peru, the treatments with CunebForte and Nutralex-K, both containing potassium-phosphite, resulted in the lowest IE and ILA, and therefore gave the best protection against $P$. infestans infection in both whole plants and detached leaflets (Table 1). In the detached leaflet assay in Ecuador, all products but one (Fitopron) resulted in zero IE, and gave zero ILA on the two potato genotypes with moderate levels of

Table 3. Information on sites and late blight control treatments evaluated in 16 field experiments carried out in Ecuador, Peru, Kenya, and Nepal ${ }^{\mathrm{a}}$

\begin{tabular}{|c|c|c|c|c|c|}
\hline Experimental sites & Locality & Altitude m.a.s.l. & $\begin{array}{l}\text { Fungicide treatments } \\
\text { (brand name) }\end{array}$ & Rate (g a.i./liter) & Sprays $^{\mathrm{b}}$ \\
\hline $\begin{array}{l}\text { Ecuador } \\
\text { Pichincha, } 2008\end{array}$ & CIP-Quito & 3,058 & $\begin{array}{l}\text { Glass-K } \\
\text { Fosphitall } 302 \\
\text { Glass-Cal } \\
\text { Cooper Feed } \\
\text { Dithane M-45 }\end{array}$ & $\begin{array}{l}3.5 \\
4.2 \\
3.2 \\
3.6 \\
2.0\end{array}$ & 10 and 6 \\
\hline Pichincha, 2010 & CIP-Quito & 3,058 & $\begin{array}{l}\text { Glass-K } \\
\text { Glass-Cu (Cu phosphite) } \\
\text { Balear 500SC (chlorothalonil) }\end{array}$ & $\begin{array}{c}0.7^{\mathrm{c}} \\
0.8 \\
2.5 \mathrm{ml} \mathrm{a.i./liter}\end{array}$ & $\begin{array}{c}8-12 \\
\text { and } 4\end{array}$ \\
\hline Tungurahua, 2009 & Pillaro & 2,817 & $\begin{array}{l}\text { Fosphitall } 302 \\
\text { Glass-Cal } \\
\text { Glass-Cu } \\
\text { Dithane M-45 }\end{array}$ & $\begin{array}{l}0.4,0.7,1.4 \\
0.4,0.7,1.4 \\
0.4,0.8,1.6 \\
2.0\end{array}$ & $\begin{array}{l}6-15 \\
\text { and } \\
4-10\end{array}$ \\
\hline $\begin{array}{l}\text { Peru } \\
\text { Cajamarca, } 2008 \\
\text { Cajamarca, } 2009 \\
\text { Junín, } 2008 \\
\text { Junín, } 2008 \\
\text { Junín, 2009 } \\
\text { Junín, } 2009 \\
\text { Pasco, 2009 }\end{array}$ & $\begin{array}{l}\text { S. Margarita } \\
\text { S. Margarita } \\
\text { Tiambra } \\
\text { Marcavalle } \\
\text { Huasahuasi } \\
\text { CIP-Huancayo } \\
\text { Oxapampa }\end{array}$ & $\begin{array}{l}2,925 \\
3,050 \\
3,015 \\
3,680 \\
2,800 \\
3,230 \\
1,797\end{array}$ & $\begin{array}{l}\text { CunebForte } \\
\text { CunebForte alternated with } \\
\text { Bravo } 500 \text { (chlorothalonil) }\end{array}$ & $\begin{array}{c}2.1 \\
2.1 \\
2.5 \mathrm{ml} \mathrm{a.i./liter}\end{array}$ & $\begin{array}{l}6 \text { and } 6 \\
7 \text { and } 7 \\
7 \text { and } 7 \\
7 \text { and } 7 \\
9 \text { and } 9 \\
4 \text { and } 6 \\
9 \text { and } 7\end{array}$ \\
\hline $\begin{array}{l}\text { Kenya } \\
\text { Nairobi, } 2009 \\
\text { Rift Valley, } 2010\end{array}$ & $\begin{array}{l}\text { Univ. of Nairobi } \\
\text { Koibatek }\end{array}$ & $\begin{array}{l}1,800 \\
1,680\end{array}$ & $\begin{array}{l}\text { Agri-Fos } 400 \\
\text { Dithane M- } 45 \text { alternated with } \\
\text { Ridomil (mefenoxam + mancozeb) }\end{array}$ & $\begin{array}{c}1.26 \\
2.0 \\
0.1+1.6\end{array}$ & $\begin{array}{l}10 \text { and } 6 \\
10 \text { and } 6\end{array}$ \\
\hline Nairobi, 2010 & Univ. of Nairobie & 1,800 & $\begin{array}{l}\text { Agri-Fos } 400 \\
\text { Fosphite (K-phosphite) } \\
\text { Dithane M-45 alternated with } \\
\text { Ridomil (mefenoxam + mancozeb) }\end{array}$ & $\begin{array}{c}1.26 \\
1.26 \\
2.0 \\
0.1+1.6\end{array}$ & 7 and 9 \\
\hline $\begin{array}{l}\text { Nepal } \\
\text { Lalitpur, 2009 }\end{array}$ & NPRP-Khumaltar & 1,360 & $\begin{array}{l}\text { Agri-Fos } 400 \\
\text { Uthane M } 45 \text { (mancozeb) }\end{array}$ & $\begin{array}{l}3.0 \\
2.8\end{array}$ & 7 and 6 \\
\hline
\end{tabular}

${ }^{a}$ Fungicide active ingredients not mentioned are shown in Table 2 or 4.

${ }^{b}$ Number of days between sprays and total number of sprays, respectively. Across all sites, all treatments in the same experiment were carried out on the same dates.

${ }^{\mathrm{c}}$ In CIP-Quito 2010, the phosphite rates were increased over the season. In the initial three sprays, $0.4 \mathrm{~g} \mathrm{~K}$-phos./liter and $0.4 \mathrm{~g}$ Cu-phos./liter were used in the Glass-K and Glass-Cu treatments, respectively. In the next three sprays, $0.7 \mathrm{~g} \mathrm{~K}$-phos./liter and $0.8 \mathrm{~g} \mathrm{Cu}-$ phos./liter were used, respectively. The last three sprays used $1.4 \mathrm{~g}$ K-phos./liter and $1.6 \mathrm{~g}$ Cu-phos./liter, respectively.

${ }^{\mathrm{d}}$ Two experiments were carried out at CIP-Huancayo in 2009.

e Two experiments were carried out at the University of Nairobi in 2010.

${ }^{\mathrm{f}}$ In NPRP-Khumaltar, the phosphite and mancozeb rates were reduced over the season. In the initial three sprays in the phosphonate treatment, $3.5 \mathrm{~g}$ Kphosphite/liter were used. In the next two sprays, $2.8 \mathrm{~g}$ a.i./liter were used. In the final spray, $2.3 \mathrm{~g}$ a.i./liter were used. In the initial three sprays in the mancozeb treatment, $3.3 \mathrm{~g}$ a.i./liter were used. In the next two sprays, $2.6 \mathrm{~g}$ a.i./liter were used. In the final spray, $2.2 \mathrm{~g}$ a.i./liter were used. 
resistance (Table 2). On the more susceptible genotype, LBR-47, four of the products resulted in zero IE and actually stopped infection: Fosphitall, Glass-K, Glass-Cal, and Glass $\mathrm{Ca}+\mathrm{Mg}$. However, lower IE and smaller LS occurred for all of the products relative to the control treatments (Table 2).

Field experiments. Phosphonate formulations used in the field trials (Table 3) were chosen based on results of the bioassays (Peru and Ecuador) and availability in the local agrochemical markets (Kenya and Nepal).

An effect of phosphonate on foliar late blight relative to the control treatment without fungicide application was seen in all experiments (data not shown). The meta-analysis demonstrated a clear effect of application rate on the efficacy of potassium-phosphite formulations across field experiments (Fig. 1). The relationship between efficacy and rate was generally linear; however, there was a slight decline in efficacy with the highest rate, which was over 4 g a.i./liter (Fig. 1). Despite the decline with the highest rate, a linear model appeared to be the best-fit to our range of data. The linear regression line $\left(E=0.113 \times \mathrm{K}\right.$-phosphite rate $-0.292 ; R^{2}=$ 0.24 ) indicated that about $2.5 \mathrm{~g}$ a.i./liter is needed for K-phosphite to give a level of control equivalent to commonly used conventional contact fungicides, and phosphonate rates above this amount tend to give better control than the conventional fungicides. A linear regression $t$ test determined that the slope of the regression line differed significantly from zero $(P<0.001)$. According to regression analysis, the efficacy of control increased by $11 \%$ for each gram of K-phosphite/liter. This is of course within the bounds of this analysis and given the assumption of linearity.

To plot the efficacy parameter, $E$, against late blight susceptibility levels of different potato genotypes, $E$ was first corrected for the effect of application rate using the linear regression function $\left[E_{\text {Corrected }}=E /(0.113 \times \mathrm{K}\right.$-phosphite rate $\left.)+0.292\right]$ derived in the analysis above. Plotting $E_{\text {Corrected }}$ against estimated susceptibility scale values of potato genotypes revealed no correlation (Fig. 2), thus demonstrating a lack of evidence in this study that phosphonate efficacy is affected by the level of susceptibility in the potato cultivar.

Economic analysis. The cost of phosphonate fungicides varied greatly across countries, as did the cost of conventional fungicides and the cost of different phosphonate products within countries (Table 4). When we compared prices of conventional fungicides at their recommended levels, i.e., spray mixes with $2.5 \mathrm{~g}$ a.i./liter with the cost of spray mixes with $2.5 \mathrm{~g}$ a.i./liter of phosphonate, the latter was competitive in some countries but not all. In Ecuador for example, only the phosphonate product Fosphitall was competitive with the conventional fungicides; the other phosphonate products sold in Ecuador were clearly more expensive at effective rates than the contact fungicide mancozeb. In Peru, the phosphonate product used in the field experiments was competitive, but mainly because of the high price of chlorothalonil. In Kenya, phosphonate appeared to be clearly less expensive than either mancozeb or the mancozeb and mefenoxam mixture. In 2011, no phosphonate product was available in the agrochemical market in Nepal.

\section{Discussion}

In all countries, the data showed that phosphonates controlled late blight on potato foliage, which is in agreement with earlier studies $(3,9,25,27,38)$. The meta-analysis across locations indicated that phosphonate is rate responsive and that rates need to be about $2.5 \mathrm{~g}$ a.i./liter to reach the efficacy of the recommended rates of conventional contact fungicides, e.g., mancozeb and chlorothalonil. Phosphonates controlled foliar late blight better than mancozeb when phosphonates were applied at higher rates than mancozeb ( 3 to $4.2 \mathrm{~g}$ a.i./liter of phosphonate compared to 2 to $2.8 \mathrm{~g}$ a.i./liter of mancozeb).

The meta-analysis was planned before some locations were included (Kenya and Nepal), and to some extent experimental design and implementation was modified for the interests of local partners, e.g., alternation of fungicides in Peru, and use of mefenoxam in Kenya. Thus, experiments were not identical, and this could have led to unexplained variability in the regression analysis. Likewise, standardization of the efficacy parameter $E$ did not correct for small differences in the concentrations of locally used fungicides (contact rates ranged from 2 to $2.8 \mathrm{~g}$ a.i./liter), nor for the use of a systemic compound in Kenya. Furthermore, we compared control efficacy based on label indications of phosphonate or phosphite concentrations. The exact concentrations of $\mathrm{HPO}_{3}{ }^{2-}$ in the commercial formulations could not be verified. Nonetheless,

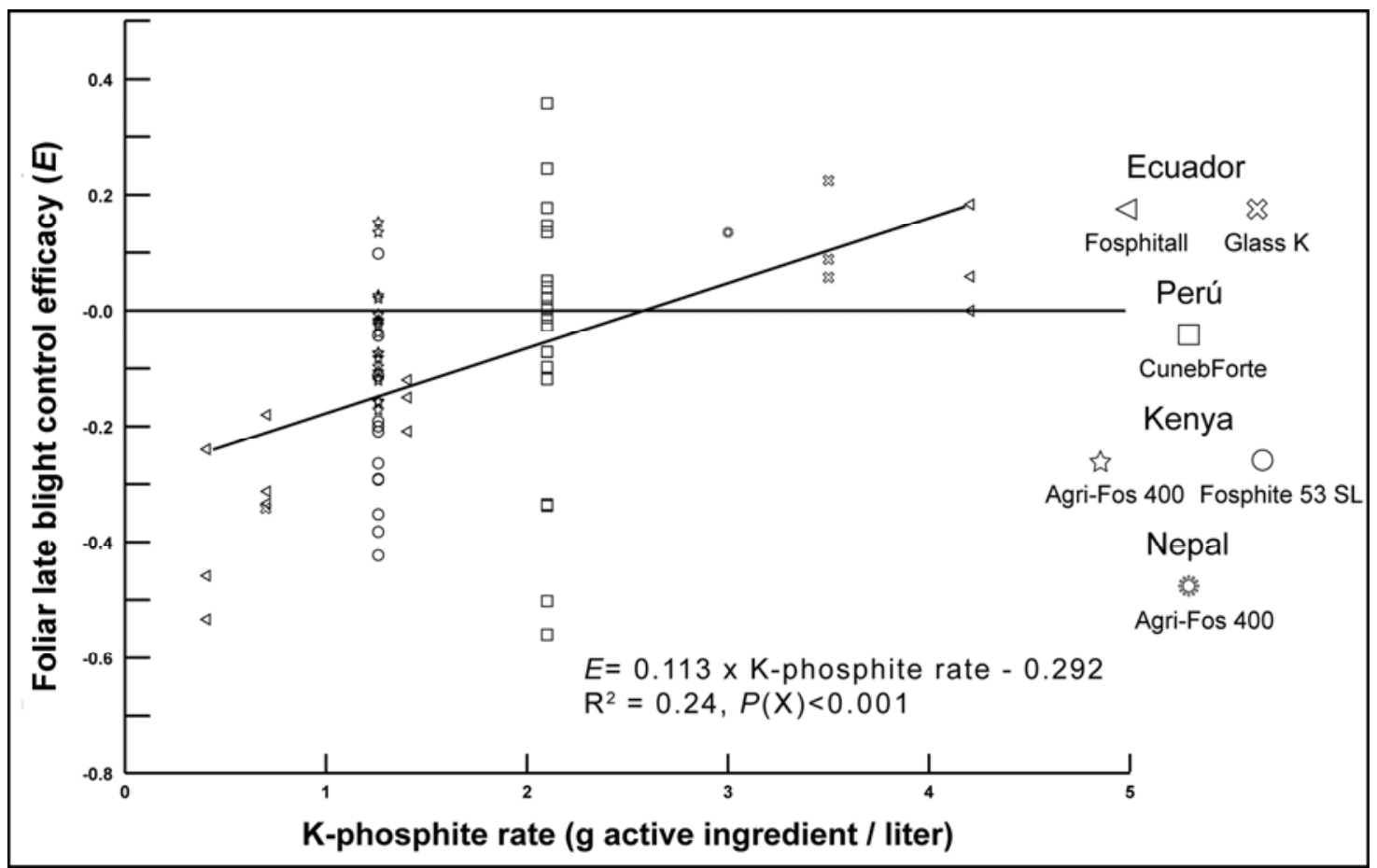

Fig. 1. Linear relationship between rate of application and control efficacy of potassium-phosphite on foliar potato late blight $(E)$ in 71 combinations of potato genotype by siteyear-K-phosphite in 15 field experiments done in Ecuador, Peru, Kenya, and Nepal. The line at $E=0.0$ indicates control efficacy equal to that of conventional fungicides applied at 2 to $2.8 \mathrm{~g}$ a.i./liter. 
the analysis produced a statistically significant relationship between rate and efficacy of phosphonates that we believe is robust. However, the factors mentioned above may have affected the accuracy of our analysis, and it would be good to see further research on the rates of phosphonate compounds needed for adequate control of foliar late blight.

As noted in the results, we chose a linear regression relationship for the range of phosphonate application rates we evaluated ( 0.4 to $4.2 \mathrm{~g}$ a.i./liter) even though there appeared to be a reduced incremental effect above $3.5 \mathrm{~g}$ a.i./liter. The linear relationship was assumed because there was only one experiment where rate was above this level, and it was therefore impossible to identify any confounding factors in that experiment that may have affected efficacy.

The use of phosphonates as an alternative to many conventional fungicides, particularly EBDC compounds, could potentially re- duce health and environmental risks. Risk reduction can be very significant when aggregated over a whole cropping season or several seasons, or over large areas. Temporal and/or spatial aggregation of benefits can be measured with the EIQ $(20,21)$ or other similar measures, and these methodologies can provide practical tools for ex ante or ex post assessment of the impacts of phosphonate use. Applying the EIQ metric to estimate the level of risk reduction that can be achieved by substituting mancozeb with the same dosage and number of phosphonate sprays over any period of time suggests that the environmental impact can be reduced by more than $60 \%$ (EIQ for mancozeb $=25.7$; EIQ for phosphonate $=$ 8.7) $(20,21)$.

Application of phosphonate has been associated with inducing increased levels of host plant resistance $(1,10,16,18,32,35)$, in addition to the direct fungitoxic effects the compounds may have

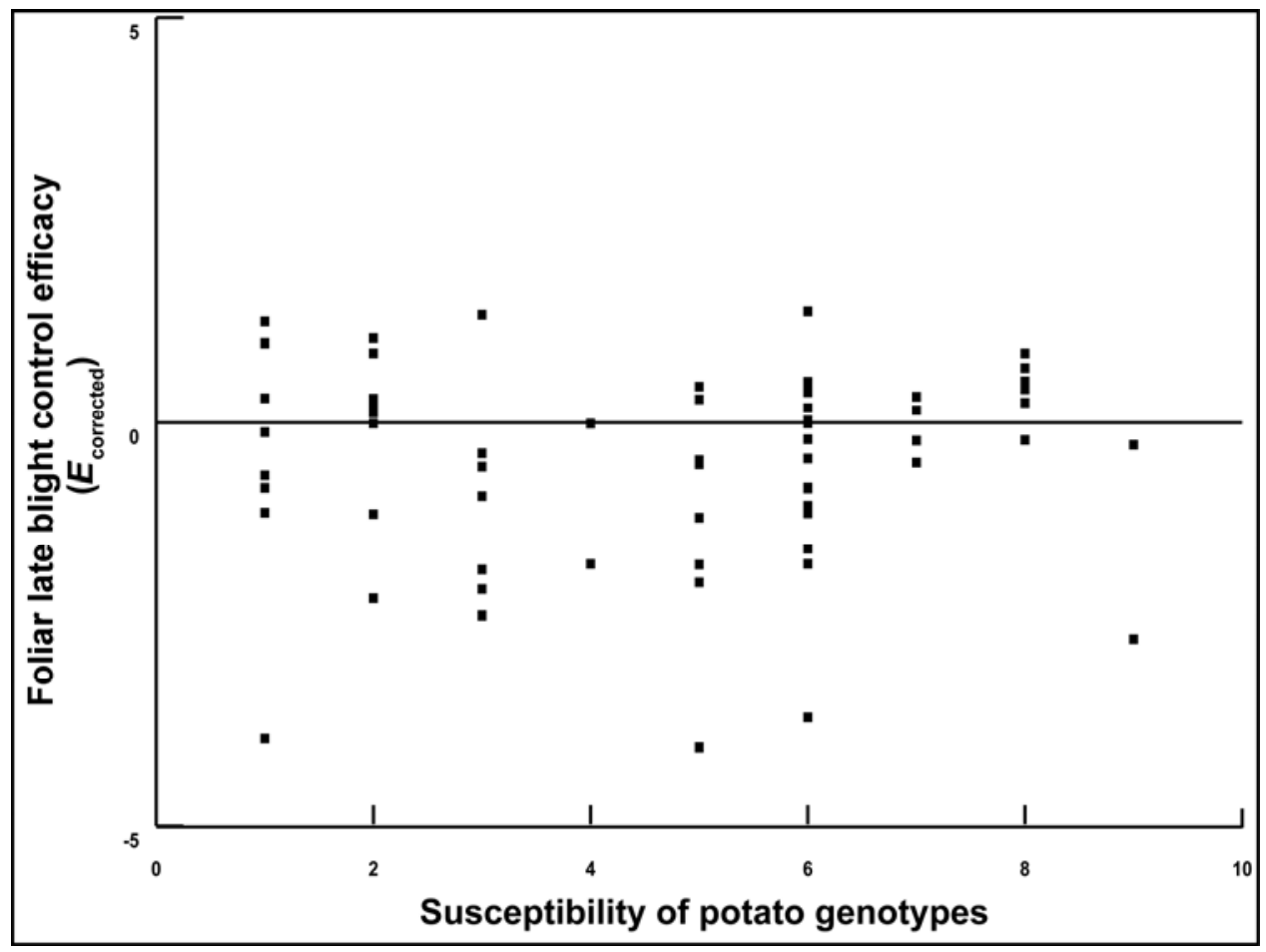

Fig. 2. No relationship between the susceptibility level of potato genotypes and control efficacy of potassium-phosphite on foliar potato late blight $(E)$ in 64 combinations of potato genotype by site-year-K-phosphite in 14 field experiments carried out in Ecuador, Peru, and Kenya. Susceptibility scale value $0=$ no susceptibility/immune. Susceptibility scale value $10=$ highly susceptible. $E$ was corrected for effect of application rate of K-phosphite; average rate of K-phosphite was $1.9 \mathrm{~g}$ a.i./liter and average rate of conventional fungicide was $2.0 \mathrm{~g}$ a.i./liter.

Table 4. Phosphonate and conventional fungicides evaluated in field experiments, retail prices, and prices for spray mixes with $2.5 \mathrm{~g}$ a.i./liter in 2011

\begin{tabular}{|c|c|c|c|c|}
\hline Country & $\begin{array}{l}\text { Fungicide } \\
\text { active ingredient }\end{array}$ & Brand name, manufacturer & $\begin{array}{l}\text { Price/liter } \\
\text { (US dollars) }\end{array}$ & $\begin{array}{l}\text { Price for } 200 \text { liters of spray mix } \\
\text { with } 2.5 \mathrm{~g} \text { a.i./liter (US dollars) }\end{array}$ \\
\hline Ecuador & $\begin{array}{l}\text { K-phosphite } \\
\text { K-phosphite } \\
\text { Ca-phosphite } \\
\text { Cu-phosphite } \\
\text { Cu-phosphite } \\
\text { Mancozeb } \\
\text { Chlorothalonil }\end{array}$ & $\begin{array}{l}\text { Glass-K, Morera } \\
\text { Fosphitall 302, Quimasoc } \\
\text { Glass-Cal, Morera } \\
\text { Cooper Feed, Arvensis Agro } \\
\text { Glass-Cu, Morera } \\
\text { Dithane M-45 NT, Dow } \\
\text { Balear } 720 \text { SC, Chimac-Agriphar }\end{array}$ & $\begin{array}{l}13.08 \\
7.25 \\
13.08 \\
12.00 \\
13.93 \\
6.75 / \mathrm{kg} \\
13.75\end{array}$ & $\begin{array}{r}11.38 \\
5.18 \\
27.59 \\
9.23 \\
14.54 \\
4.22 \\
9.55\end{array}$ \\
\hline Peru & $\begin{array}{l}\text { K-phosphite } \\
\text { Chlorothalonil }\end{array}$ & $\begin{array}{l}\text { CunebForte, Drokasa } \\
\text { Bravo } 720 \text { SC, Syngenta }\end{array}$ & $\begin{array}{l}22.80 \\
26.78\end{array}$ & $\begin{array}{l}13.58 \\
18.60\end{array}$ \\
\hline Kenya & $\begin{array}{l}\text { K-phosphite } \\
\text { K-phosphite } \\
\text { Mancozeb } \\
\text { Mefenoxam + mancozeb }\end{array}$ & $\begin{array}{l}\text { Agri-Fos 400, Agrichem } \\
\text { Fosphite 53SL, JH Biotech } \\
\text { Dithane M-45 NT, Dow } \\
\text { Ridomil Gold, Syngenta }\end{array}$ & $\begin{array}{l}5.63 \\
15.00 \\
15.00 / \mathrm{kg} \\
22.50 / \mathrm{kg}\end{array}$ & $\begin{array}{r}6.12 \\
14.15 \\
9.38 \\
11.25^{\mathrm{a}}\end{array}$ \\
\hline Nepal & $\begin{array}{l}\text { K-phosphite } \\
\text { Mancozeb }\end{array}$ & $\begin{array}{l}\text { Agri-Fos 400, Agrichem } \\
\text { Uthane M 45, United Phosphorus }\end{array}$ & $\begin{array}{l}5.00^{\mathrm{b}} \\
4.8 / \mathrm{kg}\end{array}$ & $\begin{array}{l}5.43 \\
3\end{array}$ \\
\hline
\end{tabular}

\footnotetext{
${ }^{a}$ Price for manufacturer's recommended rate of $2.5 \mathrm{~g}$ commercial product/liter (Ridomil Gold: $4 \%$ mefenoxam $+64 \%$ mancozeb).
}

${ }^{\mathrm{b}}$ Price in Australia for Agri-Fos 400, since it was not available on the local agrochemical market in Nepal. 
on pathogens $(14,16,30,35,36)$. Therefore, it is perhaps not surprising that phosphonate applied to potato has also been found to reduce damage done to tubers by oomycete pathogens such as $P$. erythroseptica $(19,37)$ and $P$. infestans $(3,9,19,24-27)$. However, phosphonates have also been found to reduce disease caused by other tuber pathogens such as Streptomyces scabies, Fusarium solani, and Erwinia carotovora (24-26). These positive secondary effects of using phosphonate could increase their competitiveness against other late blight fungicides of narrower spectrum or which do not translocate to tubers. We are not aware of reports of effects of phosphonate on damage done by non-oomycete foliar pathogens of potato.

Although our research analyzed the rate of phosphonate needed to control foliar late blight with the same efficacy as commonly used contact fungicides, it should be noted that recent studies in the highland tropics have demonstrated that late blight is sometimes inadequately controlled even with frequent (every 4 to 7 days) applications of contact fungicide $(23,28)$. At rates higher than $2.5 \mathrm{~g}$ a.i./liter, phosphonate might provide better protection than what can be achieved with conventional contact fungicides in the highland tropics where conditions of high disease pressure can be present as early as crop emergence (22). However, further studies at these higher rates are needed to see if in fact the rate-response function changes, or if there are other adverse effects such as phytotoxicity, which has been reported at higher rates (37).

We were able to find only one previously published study in which the efficacy of phosphonates on foliar late blight was evaluated in such a way that we could compare results. Researchers from Cornell University used rates from 2.1 to $2.5 \mathrm{~kg}$ a.i./ha potassium phosphonates in 238 liters of water in up to eight sprays, which generally controlled tuber blight better than chlorothalonil, and foliar late blight about as well as the conventional fungicide (27). In all of our field experiments, the products were applied with hand-pump backpack sprayers until runoff, which results in much higher application volumes than used in the study above. We have found that on a mature potato crop, spraying until run-off can consume up to 1,000 liters/ha, which at a concentration of $2.5 \mathrm{~g}$ a.i./liter results in $2.5 \mathrm{~kg}$ a.i./ha. Thus, we conclude that the results from the Cornell study are generally consistent with our findings.

Efficacy of phosphonate to control foliar late blight was also evaluated in Northern Ireland (9) and in a recent 3-year field study in Canada (38). However, in neither case were the phosphonate products directly compared with similar amounts of contact fungicide, so interpretation of the results is difficult.

In each location in our study, at least one formulation of phosphonate was economically competitive with either mancozeb or chlorothalonil when equal concentrations of active ingredient were compared, except in Nepal where no phosphonates are currently available (Table 4). In Kenya, phosphonate was clearly the most economical disease control option for farmers. Extension workers in Kenya should be encouraged to validate our findings with further experimentation given the potential economic, health, and environmental benefits gained by using available phosphonate compounds $(16,20,21)$. Nonetheless, care should be taken when relying on the many phosphonate products found in local agrochemical markets, which may be of varying quality. Local experimentation is advisable to verify efficacy and to build trust in products and concentrations of active ingredients listed on product labels.

We found some difference in control efficacy among different phosphonate formulations. Above all, the efficacy of $\mathrm{Cu}$-phosphites was slightly higher than the effect of $\mathrm{K}$ - and Ca-phosphites in susceptible genotypes studied in Ecuador (data not shown). This is consistent with the findings of Lobato et al. (26), who reported higher antimicrobial effect of $\mathrm{Cu}$-phosphite than of $\mathrm{K}$ - and $\mathrm{Ca}$ phosphites on pathogens causing potato tuber diseases. The improved control effect of $\mathrm{Cu}$-phosphites is most likely a result of the fungicidal effect of the $\mathrm{Cu}^{++}$ion alone.

Previous work had indicated that phosphonate efficacy may be cultivar dependent $(9,25,38)$. We failed to identify a correlation between efficacy and the resistance level of potato cultivars across locations, but we did have some evidence for cultivar effects within the Peru study which may or may not have been associated with resistance. The experiments in Peru were not designed to test this phenomenon, so we do not present the data here. However, we do plan to continue research in this area and commence studies that can elucidate how the infection processes of $P$. infestans on potato are slowed down by phosphonates.

Additional investigation is needed to clarify the possible interaction of phosphonate efficacy with host genotype and the quantitative fungicidal effect of different phosphonate compounds on specific epidemic parameters. Thus, applied research is warranted to optimize the usage of phosphonates on specific host genotypes, especially related to rates, timing of applications, effects of environmental factors, and additive or synergistic effects with other chemical compounds.

\section{Acknowledgments}

This work was supported by the International Potato Center (CIP); the United States Agency for International Development (USAID) through the project, "Tackling the food price crisis in Eastern and Central Africa with the humble potato: Enhanced productivity and uptake through the 3G revolution"; the OPEC Fund for International Development; Jose Morera S.L., Spain; the Danish International Development Assistance (DANIDA); and by the Swiss Agency for Development and Cooperation (SDC) through the Papa Andina initiative.

\section{Literature Cited}

1. Afek, U., and Sztejnberg, A. 1989. Effects of fosetyl-Al and phosphorous acid on scoparone, a phytoalexin associated with resistance of citrus to Phytophthora citrophthora. Phytopathology 79:736-739.

2. Andrade-Piedra, J. L., Hijmans, R. J., Forbes, G. A., Fry, W. E., and Nelson, R. J. 2005. Simulation of potato late blight in the Andes. I: Modification and parameterization of the LATEBLIGHT model. Phytopathology 95:1191-1199.

3. Andreu, A. B., Guevara, M. G., Wolski, E. A., Daleo, G. R., and Caldiz, D. O. 2006. Enhancement of natural disease resistance in potatoes by chemicals. Pest Manage. Sci. 62:162-170.

4. Anonymous. 2005. Official journal of the European Union, commission directive 2005/72/EC of 21 October 2005 amending council directive 91/414/EEC to include chlorpyrifos, chlorpyrifos-methyl, mancozeb, maneb, and metiram as active substances. Retrieved 7 November 2011 from http://eurlex.europa.eu/LexUriServ/LexUriServ.do?uri=OJ:L:2005: 279:00 63:0069:EN:PDF

5. Campbell, C. L., and Madden, L. V. 1990. Introduction to Plant Disease Epidemiology. John Wiley \& Sons, New York.

6. Cohen, Y., and Coffey, M. D. 1986. Systemic fungicides and the control of oomycetes. Annu. Rev. Phytopathol. 24: 311-338.

7. Cole, D. C., Carpio, F., Math, J. J., and Léon, N. 1997. Dermatitis in Ecuadorean farm workers. Contact Dermatitis 37:1-8.

8. Cole, D. C., Sherwood, S., Crissman, C. C., Barrera, V., and Espinosa, P. 2002. Pesticides and health in highland Ecuadorian potato production: Assessing impacts and developing responses. Int. J. Occup. Environ. Health 8:182-190.

9. Cooke, L. R., and Little, G. 2002. The effect of foliar application of phosphonate formulations on the susceptibility of potato tubers to late blight. Pest Manage. Sci. 58:17-25.

10. Dunstan, R. H., Smillie, R. H., and Grant, B. R. 1990. The effects of subtoxic levels of phosphonate on the metabolism and potential virulence factors of Phytophthora palmivora. Physiol. Mol. Plant Pathol. 36:205-220.

11. Edwards, D. 2005. Registration eligibility decision for mancozeb. US Environmental Protection Agency (EPA). Retrieved 7 November 2011 from http://www.epa.gov/oppsrrd1/REDs/mancozeb_red.pdf.

12. FAOSTAT. (Current) Food and agricultural organization of the United Nations, Rome, Italy. Retrieved 15 November 2011 from http://faostat.fao.org/.

13. Fenn, M. E., and Coffey, M. D. 1984. Studies on the in vitro an in vivo antifungal activity of fosetyl-Al and phosphorous acid. Phytopathology 74:606-611.

14. Fenn, M. E., and Coffey, M. D. 1989. Quantification of phosphonate and ethyl phosphonate in tobacco and tomato tissues and significance for the mode of action of two phosphonate fungicides. Phytopathology 79:76-82.

15. Fry, W. E. 1978. Quantification of general resistance of potato cultivars and fungicide effects for integrated control of potato late blight. Phytopathology 68:1650-1655.

16. Guest, D., and Grant, B. 1991. The complex action of phosphonates as antifungal agents. Biol. Rev. 66:159-187.

17. Haverkort, A. J., Boonekamp, P. M., Hutten, R., Jacobsen, E., Lotz, L. A. P., Kessel, G. J. T., Visser, R. G. F., and Vossen, E. A. G. 2008. Societal costs of late blight in potato and prospects of durable resistance through cisgenic modification. Potato Res. 51:47-57.

18. Jackson, T. J., Burgess, T., Colquhoun, I. J., and Hardy, G. E. StJ. 2000. 
Action of the fungicide phosphite on Eucalyptus marginata inoculated with Phytophthora cinnamomi. Plant Pathol. 49:147-154.

19. Johnson, D. A., Inglis, D. A., and Miller, J. S. 2004. Control of potato tuber rots caused by oomycetes with foliar applications of phosphorous acid. Plant Dis. 88:1153-1159.

20. Kovach, J., Petzoldt, C., Degni, J., and Tette, J. 1992. A method to measure the environmental impact of pesticides, New York's Food Life Sci. Bull. 139:1-8.

21. Kromann, P., Pradel, W., Cole, D., Taipe, A., and Forbes, G. A. 2011. Use of the environmental impact quotient to estimate health and environmental impacts of pesticide usage in Peruvian and Ecuadorian potato production. J. Environ. Prot. 2:581-591.

22. Kromann, P., Taipe, A., Andrade-Piedra, J. L., Munk, L., and Forbes, G. A. 2008. Preemergence infection of potato sprouts by Phytophthora infestans in the highland tropics of Ecuador. Plant Dis. 92:569-574.

23. Kromann, P., Taipe, A., Perez, W. G., and Forbes, G. A. 2009. Rainfall thresholds as support for timing fungicide applications in the control of potato late blight in Ecuador and Peru. Plant Dis. 93:142-148.

24. Lobato, M. C., Machinandiarena, M. F., Tambascio, C., Dosio, G. A. A., Caldiz, D. O., Daleo, G. R., Andreu, A. B., and Olivieri. F. P. 2011. Effect of foliar applications of phosphite on post-harvest potato tubers. Eur. J. Plant Pathol. 130:155-163.

25. Lobato, M. C., Olivieri, F. P., Altamiranda, E. A. G., Wolski, E. A., Daleo, G. R., Caldiz, D. O., and Andreu, A. B. 2008. Phosphite compounds reduce disease severity in potato seed tubers and foliage. Eur. J. Plant Pathol. 122:349-358.

26. Lobato, M. C., Olivieri, F. P., Daleo, G. R., and Andreu, A. B. 2010. Antimicrobial activity of phosphites against different potato pathogens. J. Plant Dis. Prot. 117(3):101-109.

27. Mayton, H., Myers, K., and Fry, W. E. 2008. Potato late blight in tubers The role of foliar phosphonate applications in suppressing pre-harvest tuber infections. Crop Prot. 27:943-950.

28. Mekonen, S., Alemu, T., Kassa, B., and Forbes, G. 2011. Evaluation of contact fungicide spray regimes for control of late blight (Phytophthora infestans) in southern Ethiopia using potato cultivars with different levels of host resistance. Trop. Plant Pathol. 36:21-27.

29. Nelson, R., Mundt, C., Orrego, R., Ortiz, O., Fredrix, M., Tenorio, J., and Vien, N. V. 2001. Working with resource-poor farmers to manage plant diseases. Plant Dis. 85:684-695.

30. Niere, J. O., Deangelis, G., and Grant, B. R. 1994. The effect of phospho- nate on the acid-soluble phosphorus components in the genus Phy tophthora. Microbiology 140:1661-1670.

31. Orozco, F. A., Cole, D. C., Forbes, G. A., Kroschel, J., Wanigaratne, S., and Arica, D. 2009. Monitoring adherence to the international FAO code of conduct on the distribution and use of pesticides - Highly hazardous pesticides in central Andean agriculture and farmers' rights to health. Int. J. Occup. Environ. Health 15:255-268.

32. Ouimette, D. G., and Coffey M. D. 1989. Phosphonate levels in avocado (Persea americana) seedlings and soil following treatment with fosetyl-Al or potassium phosphonate. Plant Dis. 73:212-215.

33. Oyarzún, P., Garzón, C., Leon, D., Andrade, I., and Forbes, G. 2005. Incidence of potato tuber blight in Ecuador. Am. J. Potato Res. 82:117-122.

34. Papademetriou, M. K., ed. 2008. Proceedings; Workshop to commemorate the international year of the potato - 2008. Bangkok, Thailand. Food and agricultural organization of the United Nations, regional office for Asia and the Pacific. Retrieved 7 October 2011 from ftp://ftp.fao.org/docrep/ fao/010/i0200e/i0200e00.pdf.

35. Smillie, R. H., Grant, B. R., and Guest, D. I. 1989. The mode of action of phosphate: Evidence for both direct and indirect modes of action on three species of Phytophthora in plants. Phytopathology 79:921-926.

36. Stehmann, C., and Grant, B. R. 2000. Inhibition of enzymes of the glycolytic pathway and hexose monophosphate bypass by phosphonate. Pestic. Biochem. Physiol. 67(1):13-24.

37. Taylor, R. J., Pasche, J. S., and Gudmestad, N. C. 2011. Effect of application method and rate on residual efficacy of mefenoxam and phosphorous acid fungicides in the control of pink rot of potato. Plant Dis. 95:9971006

38. Wang-Pruski, G., Coffin, R. H., Peters, R. D., Al-Mughrabi, K. I., Platt, H. W., Pinto, D., Veenhuis-MacNeill, S., Hardy, W., Lim, S., and Astatkie, T. 2010. Phosphorous acid for late blight suppression in potato leaves. Am. J. Plant Sci. Biotech. 4:25-29.

39. Wesseling, C., Corriols, M., and Bravo, V. 2005. Acute pesticide poisoning and pesticide registration in Central America. Toxicol. Appl. Pharmacol. 207:S697-S705.

40. Williams, D. J., Beach, B. G. W., Horrière, D., and Maréchal, G. 1977. LS74-783; a new systemic fungicide with activity against Phycomycete diseases. Pages 565-573 in: Proc. Br. Crop Prot. Conf. 11:32-34. Brighton, UK.

41. Yuen, J. E., and Forbes, G. A. 2009. Estimating the level of susceptibility to Phytophthora infestans in potato genotypes. Phytopathology 99:782-786. 